\title{
The Prophet and Divine Manifestation: On the Translation of the Word "Prophet" in the Shona Union Bible ${ }^{1}$
}

\author{
LOVEMORE TOGARASEI (UNISA)
}

\begin{abstract}
The translators of the Shona Union Bible of 1950, which happens to be the commonly used version of the Bible among the Shona of Zimbabwe, did not translate the word "prophet". Instead, they chose to transliterate it. This choice is rather strange, considering the key role of this office in any religion. Other recent translations have offered Shona translations of this term. The reception of the new translations has been mixed, and many Shona Bible readers still prefer the 1950 Shona Union Bible. What were the possible reasons for the early missionaries' decision to leave the term untranslated? How could this term best be translated? This paper attempts to answer these questions. It takes seriously the politics of Bible translation as has already been observed by scholars in the sphere of Bible translation. The paper considers the Hebrew world of the term, and then explores the Shona (African) religious worldview to seek possible offices that could be compared to the Hebrew prophet. The paper concludes that svikiro was the right term to translate the term prophet.
\end{abstract}

KEYWORDS: Prophet; Divine Manifestation; Translation; Shona; Svikiro; Missionaries; African Traditional Religion.

\section{A INTRODUCTION}

Because God cannot be seen, human beings have ways of representing God. Thus there are several divine epiphanies and theophanies within various religions of the world. For example, in the Hebrew Bible (HB), divine manifestation occurs through the pillar of cloud and the pillar of fire (Exod 13:21, 14:19)

* Article submitted: 15/05/2017; peer-reviewed: 13/09/2017; accepted: 3/10/2017. Lovemore Togarasei, "The Prophet and Divine Manifestation: On the Translation of the Word "Prophet" in the Shona Union Bible," Old Testament Essays 30 no. 3 (2017): 821-834. DOI: https://doi.org/10.17159/2312-3621/2017/v30n3a16

1 This article was originally prepared for and presented at the North-West University/University of Botswana collaborative workshop on Divine Epiphanies at the University of Botswana, Gaborone, 3 October 2016. I am grateful to colleagues who made constructive observations. I also appreciate comments by anonymous reviewers. They strengthened the argument of this paper. 
and the ark of the covenant (2 Sam 6:2). ${ }^{2}$ In the NT, divine manifestation happened in the form of a dove (Matt 3:16, John 1:32) and tongues of fire (Acts 2:3). Among most Africans, God manifests himself through natural phenomena like lightning, thunder, drought, diseases and other plagues. ${ }^{3}$ These divine manifestations, however, do not have meaning unless they are interpreted by the prophet, the priest, or any other religious practitioner, by whatever name they are known in a specific religion. These religious practitioners mediate between the divine and the human beings to render divine manifestations meaningful. Representing God in some physical or concrete form becomes even necessary when introducing one's own God into a new society. The early missionaries in Africa had to struggle with this issue when they introduced the Christian God to Africans. They had to find indigenous terms for expressing Christian theology. The task became even more difficult as they translated the Bible into the indigenous languages. ${ }^{4}$ It has been observed by several scholars that the entire process of translating the Bible into indigenous languages was strongly influenced by the missionary attitude towards Africa and its people. ${ }^{5}$ Unfortunately, being in tandem with the colonial thinking of the time, missionaries viewed African religion and culture as only worth of condemnation. Below is a sample of some early missionaries' views of African religion and culture:

- ...the Shona "give to God the name of Mulungo (Murenga) but all this in much confusion, darkness and obscurity."6

- "truly a mumbo jumbo of beliefs so superstitious [as] to be ridiculous."7

- “On my way to Plaatberg I passed by a Basuto village where the people were dancing over corn previous to sowing. There were three baskets of corn on the ground and the people... [were]... dancing and twisting with strange antics past it. I asked them what they were doing. They said they were praying to God to give them rain and plenty corn. I spoke to them

2 God also manifests in appearances of sacred animals or some other unusual phenomena like mighty winds.

3 James Amanze, African Christianity in Botswana (Gweru: Mambo Press, 1998), 7-8.

4 Among the Shona, the debate over the indigenous name to be used to translate the Christian God raged for a long time since the era of missionary successes in the 1890s to the 1960s when a general consensus was reached on the use of Mwari. See Dora R. Mbuvayesango, "How Local Divine Powers were Suppressed: A Case of Mwari of the Shona," in Other Ways of Reading: African Women and the Bible, ed. Musa W. Dube (Atlanta: Society of Biblical Literature, 2001), 65-67.

5 See footnote 10 for examples of such scholars.

6 Paul H. Gundani, "Views and Attitudes of Missionaries toward African Religion in Southern Africa during the Portuguese Era," R\&T 11 (2004): 300.

7 Gundani, "Views and Attitudes,” 300. 
on their folly and exhorted them to abandon their sinful customs and pray to God."8

- “(Batswana) ... had no religious ideas at all, or at least none worth bothering about ... all their customs were wicked, the only proper response to them was denunciation” (Robert Moffat). ${ }^{9}$

From a postcolonial perspective, African scholars have highlighted the Eurocentric attitude of the missionary translators of the Bible. ${ }^{10}$ It was noted that missionary translators were caught between utilising and denouncing African religion for evangelisation. ${ }^{11}$ This paper follows these earlier observations by focusing on the translation of the word "prophet" in the Shona Union Bible of 1950. I argue that the prophet is a key figure in divine manifestation, and that the translation of this word into vernacular languages had critical theological and ideological implications. Of particular interest is the missionary translators' decision to leave the word untranslated, rendering it instead in the transliteration form of muporofita. ${ }^{12}$ What were the theological and ideological reasons for this translation? This paper argues that this choice was indeed colonising as it refused to acknowledge the Shona traditional religion's cosmology based on the negative attitude that missionaries had towards African religion and culture. As Victor I. Ezigbo has correctly observed,

... the theological language and content of a Christian theology designed for African contexts must embrace and interact with the indigenous religious thought forms of Africa. ${ }^{13}$

8 Wesleyan missionary, 1839. See Gabriel M. Setiloane, The Image of God among the Sotho-Tswana (Rotterdam: A. A. Balkema, 1976), 15.

9 Cited by Lovemore Togarasei, "Paul and Interreligious Dialogue: Insights for Mission in Africa,” Miss 43/2 (2015): 156-157.

10 For example, Musa W. Dube, "Consuming a Cultural Time Bomb: Translating Badimo into 'Demons' in the Setswana Bible," JSNT 73 (1999): 33-59; Aloo O. Mojola, "Post-Colonial Translation Theory and the Swahili Bible," in Bible Translation and African Languages, ed. Gosnell L. O. R. Yorke and Peter M. Renju (Nairobi: Acton Publishers, 2004), 77-104, and Lovemore Togarasei, "The Shona Bible and Politics of Bible Translation," SWC 15/1 (2007): 51-64.

11 This point is strongly presented by Mbuvayesango, "How Local," 65-67 and Gomang S. Ntloidibe-Kuswani, "Translating the Divine: The Case of Modimo in the Setswana Bible," in Other Ways of Reading: African Women and the Bible, ed. Musa W. Dube (Atlanta: Society of Biblical Literature, 2001), 78-97.

12 The transliteration of the word prophet is also found in other African Bible translations like the Sotho-Tswana, Zulu/Ndebele and Chewa Bible translations. While I pay particular attention to the Shona Bible and religion here, this issue can generally be applied to the African Bible and religion.

13 Victor I. Ezigbo, "Religion and Divine Presence: Appropriating Christianity from within African Indigenous Religions' Perspective,” in African Traditions in the Study of Religion in Africa (ed. Afe Adogame, Ezra Chitando, and Bolaji Bateye; Surrey: 
Translation of the Bible into the indigenous languages is critical in achieving this objective. ${ }^{14}$ Informed by the translation theory that, "The translator needs knowledge not only of the source languages and source world but also of the receptor language and receptor world,"15 and M. Baker's theory that translation and interpretation are part of the institution of war and conflict management, ${ }^{16}$ I explore the possible reasons for missionaries' transliteration. To do so, I consider the Hebrew world of the term prophet, reflect on the Shona world of the term svikiro and then conclude that svikiro was supposed to be used to translate the word prophet into Shona.

\section{B PROPHET IN HEBREW BIBLE}

The HB provides us with several insights into Israelite understanding of a prophet. Archaeological findings from the Middle East also aided our understanding of prophecy in Israel. ${ }^{17}$ Be that as it may, a final definition of a prophet remains elusive. This is because of at least three reasons. Firstly, the Bible itself does not provide a definition of a prophet, but only tell of activities of the prophets. Secondly, there is a multiplicity of prophetic functions, making it very difficult to come up with a simple definition of a prophet. Thirdly, there is often a tendency when constructing definitions to do so using one's present/contemporary understanding of a word. This often results in anachronisms. However, apart from these problems, several attempts have been made to define a prophet in the context of the HB and, indeed, several definitions have been proffered. There are basically two approaches used to define a prophet: through linguistic analysis of terms for the word, prophet and through an analy-

Ashgate, 2012), 187-204. Victor I. Ezigbo ("Religion and Divine Presence: Appropriating Christianity from within African Indigenous Religions' Perspective,” in African Traditions in the Study of Religion in Africa (ed. Afe Adogame, Ezra Chitando, and Bolaji Bateye; Surrey: Ashgate, 2012), 188, adds that to achieve this objective, there may be a requirement to drop some classical Western Christian languages and expressions, however orthodox they may appear to be and taking on uniquely African expressions.

14 The point is emphasised by O. P'Bitek (cited by Ezigbo, Religion and Divine Presence, 188), who propounds that expressing African ideas in non-African languages results in losing the African languages' stock of common images expressing the Africans' ways of looking at things. This, for me, is the problem of transliteration.

15 Togarasei, “Shona Bible,” 55.

16 Mona Baker, Translation and Conflict: A Narrative Account (London: Routledge, 2006), 2.

17 Helmer Ringgren, "Prophecy in the Ancient Near East," in Israel's Prophetic Tradition: Essays in Honour of Peter Ackroyd, ed. Richard Coggins, Anthony Phillips, and Michael Knibb (Cambridge: Cambridge University Press, 1982), 1-11 provides a detailed discussion of new light thrown on origins of Israelite prophecy using evidence from archaeological findings from sites like Mari. He discusses terms like mahhu and traditions like that of Zimri-lim. 
sis of prophetic traditions in the Pentateuch and the prophetic books. ${ }^{18}$ I follow this approach here as I attempt to understand the prophet as the medium of divine manifestation in the HB.

Three linguistic terms can be identified from the literature on prophecy in the HB. These help us to understand what the Israelites considered a prophet to be. The first term is ish ha'elohim (man of God). The term is widely used in the HB to refer to people like Samuel (1 Sam 9:6, 1 Kgs 13:1, 17:18), Elijah (for whom the title is used several times, e.g. 2 Sam 1:10) and David (2 Chr $8: 14$, Neh 7:24). The sum total of its use suggests the definition of a prophet as a designated person; a person who is consecrated to carry out religious functions. Such a person has to avoid certain taboos, the violation of which would make him/her fail in their functions. The person had to perform deeds of power as evidence of possession by the spirit of God.

The second term is roeh or hozeh. According to J. Lindblom, roeh and hozeh are different dialects with the same meaning. ${ }^{19}$ They both mean a seer. G. Fohrer even argues that these words also mean the same as nabi, the word we discuss here separately as the third linguistic term. ${ }^{20}$ Fohrer is of the opinion that whereas roeh and hozeh were used by nomadic cultures, nabi is the term used by settled agrarian cultures. ${ }^{21}$ A seer was a person with a gift of seeing beyond normal sight. He or she seer could see what was happening at a distance, e.g. Samuel who could see that Saul's father's asses had been found (1 Sam 9:20). Such a person was able to predict the future and could see what happened in the past. For Dean Stanley,

The word "seer," by which the "prophet" was originally called, implies that visions were the original mode of revelation to the prophets. These visions, in the case of the prophets of the OT, were almost always presented in images peculiarly appropriate to the age or the person to whom they appear, and almost always conveying some lofty conception of the divine nature. ${ }^{22}$

Thus following this train of thought, a prophet can be defined as a person who has a gift of seeing and revealing things hidden from common people with the chief medium being second or extraordinary sight. The seer can see and reveal divine manifestation, as A New Standard Bible Dictionary has captured it,

18 Johannes Lindblom, Prophecy in Ancient Israel (Oxford: B. Blackwell, 1962), 62. 19 Lindblom, Prophecy, 62.

20 Georg Fohrer, Introduction to the Old Testament (London: SPCK, 1976).

21 This probably explains texts like 1 Sam 9:9 that show a transition from the use of roeh/hozeh to use of nabi.

22 Dean A. P. Stanley, History of the Jewish Church (New York: Charles Scribner's Sons, 1891), 380. 
According to the meaning of this Hebrew word, a prophet is one who "sees", "one whose sight pierces through the veil that hides the world of divine things, or one for whom this veil is lifted occasionally so that he obtains an inner knowledge of the realities beyond. ${ }^{23}$

The third term is nabi. It is the most common word used to translate prophet in the HB. It comes from the verb niba, which means to proclaim, to announce or to speak out. ${ }^{24} \mathrm{~A}$ nabi is therefore a prophet, a proclaimer, a spokesperson or an announcer. In the HB, the word is used for spokespersons of God, specifically divinely or charismatically authorised spokespersons. This is because all Israelite prophets underline a call by the divine being. Amos puts his call emphatically:

I am no prophet, nor a prophet's son, but I am a herdsman and a dresser of sycamore trees, and the Lord took me from following the flock, and the Lord said to me, "God, prophesy to my people, Israel” (Amos 7:14-15).

Thus following this line of argument, a prophet is not a politician, a foreteller, a philosopher, a political scientist who can predict election results or a meteorologist who can foretell the weather. Rather, as J. Lindblom emphasises, a prophet is a religious person, a homines religiosi. ${ }^{25}$ The prophet has the ability to experience the divine in an original/special way and then announce what he/she has heard or seen.

The three linguistic terms show that a prophet is somebody who speaks something for a deity, and is inspired through revelation. He/she can be considered as a channel of communication or a bridge between the deity and the people. Through a prophet, God manifests Himself to the people.

An analysis of prophetic traditions in the Pentateuch and the prophetic books also helps in further defining the term prophet. The first person to be called a prophet in the HB was Abraham (Gen 20:7). Like the later prophets, he received a call (Gen 12), made a covenant with God (Gen 12), spoke to God, and mediated between human beings and God. This is also true of Moses who can be described as the ideal prophet against whom all other prophets would later be measured (Deut 18:15, 18). He was a legislator, a warrior and a founder of a cult. He received a call in which God manifested himself in form of a fire (Exod 3:1-6). He performed miracles, saw visions (Exod 33:9, 18:23) and spoke to God face to face (Exod 33:11). He interceded on behalf of the people and even provided criteria for distinguishing true from false prophets (Deut 18:22). He also promised the coming of a great prophet (Deut 18:5).

23 Jacobus W. Melanchton, ed., "Prophet," in A New Standard Bible Dictionary (New York and London: Funk \& Wagnalls Company, 1925), 739.

24 Lindblom, Prophecy, 65.

25 Lindblom, Prophecy, 65. 
From the Pentateuchal traditions, we learn that prophecy was not limited to men. Miriam is also called a prophetess (Exod 15:20). Another important prophetess is Huldah (2 Kgs 22), who was the first person to declare a book canonical. Isaiah's wife is also called a prophetess (Isa 8:1) although we do not know whether she was one in her own right or by virtue of being Isaiah's wife. Prophetic traditions present all the characteristic features of prophets that we find in Pentateuchal figures called prophets: call, performance of miracles, mediation between God and the people, and so forth. However, they also add more to our understanding of a prophet in the Israelite tradition. For example, we learn from them that prophets were not only speakers but also actors. We learn about a number of prophets who expressed their prophetic messages through symbolic actions. Zedekiah made for himself horns of iron (1 Kgs 22:11), just as Jeremiah would make a wooden yoke and later an iron yoke (Jer 22:7), Elisha told the king of Israel to shoot with bow and arrows in the direction of Syria in order to secure victory (2 Kgs 13:15), Isaiah went about naked and barefoot for three years (Isa 20:3) while Ezekiel cooked his food using human waste to make fire (Ezek 4:12).

Hebrew Bible prophetic traditions also provide more information that helps us get a full picture of what a prophet was in ancient Israel. Some prophets had prophetic followers called bene ha nebiim (sons of the prophets). This phrase appears ten times in the HB. 1 Samuel 10 mentions a band of prophets while prophets like Elijah and Isaiah had prophetic disciples. The patrons of prophetic disciples/sons of the prophets were called prophetic fathers. W. H. Wolff, who studied this phenomenon closely, notes that only the prophetic father received revelations from God. ${ }^{26}$ The roles of the sons of the prophets was therefore to carry the message of the father to the people, to help the father get into trance through music, to remember the words of the father, to provide the father with moral support, and sometimes to cheer up Israelite soldiers in war. We also learn from these traditions that Israelite prophets received divine messages through various methods that included ecstasy, visions, dreams, urim and thumim (a form of casting lots) and direct verbal communication. They would, in turn, also use different methods to communicate the messages, including direct verbal communication, symbolic actions, in written form, and the like. Israelite prophets served many roles. In accordance with the will of God, they chose kings, gave them support and counsel, predicted victory or defeat in wars, they denounced social injustices, warned the people against idol worship, and were voices of admonition concerning the proper service to God and humanity.

From the above discussion, it is clear that the phenomenon of prophecy was quite widespread that it is unwise to propose a simple definition of a prophet. A great deal therefore has to be considered in attempting a definition.

26 Hans. W. Wolff, Hosea (Philadelphia: Fortress Press, 1988). 
This includes analysis of the Greek word prophetes from which the English word prophet is derived. Prophetes emphasises the role of a prophet as a forth speaker or a preacher who speaks on behalf of a deity. ${ }^{27}$ In this sense, a prophet is a medium who proclaims words coming from a deity (God). Considering this and the discussion above, I therefore define a prophet as a person who has experienced divine inspiration and who speaks or acts in terms of what he/she has experienced about divine manifestation. Thus Lindblom's emphasis on the prophet being a homines religiosi (religious being) should always be borne in mind when defining a prophet in the HB tradition.

\section{SVIKIRO AMONG THE SHONA}

To understand the svikiro among the Shona of Zimbabwe, one has to consider the religion of the Shona in general. The Shona believe in God the creator known by different names; Mwari, Nyadenga, Chidzachepo, Mutangakugara, Wokumusoro, Dzivaguru, among others. Today, Mwari is the most common word used for this God. Mwari is considered transcendental, remote and far removed from human beings and their daily concerns and, as a form of respect, Mwari is not approached directly. Rather, Mwari (God) is approached through ancestors who are the spirits of one's deceased parents. The ancestors are therefore intermediaries between God and human beings. But because God and the ancestors are spirits, they manifest ${ }^{28}$ themselves through a svikiro (spirit medium). ${ }^{29}$ The word svikiro ${ }^{30}$ is derived from the verb kusvika, which means to arrive or to reach a place. God (and the ancestral spirits) therefore arrives among the people through a svikiro.

To be a svikiro, one has to receive a call. This call often begins with an illness of the would-be svikiro. Illness is therefore a form of divine manifestation through which the ancestors communicate their need to possess the medi-

27 Bernhard W. Anderson, The Living World of the Old Testament, 4th ed (Harlow: Longman, 1993), 248.

28 Divine (Godly) manifestation among the Shona, as in other African societies such as the Xhosa of South Africa, mainly occurs through forces of nature such as rain, drought, disease, etc. See Janet Hodgson, "A Battle for Sacred Power: Christian Beginnings among the Xhosa," in Christianity in South Africa: A Political, Social and Cultural History, ed. Richard Elphick and Rodney Davenport (Claremont: David Philip, 1997), 69.

29 Even in the Mwari cult at Matopos where Mwari was believed to communicate with people directly, Mwari did so through a svikiro (medium). See Michael F. C. Bourdillon, Where are the Ancestors? Changing Culture in Zimbabwe (Harare: UZ Publications, 1997), 74, and Leslie S. Nthoi, Contesting Sacred Space: A Pilgrimage Study of the Mwali Cult of Southern Africa (Trenton: Africa World Press, 2006), 18).

30 Svikiro is often used of family spirit medium while the tribal or territorial spirit medium is called a mhondoro. See Ignatius M. Zvarevashe, "Shona Religion," in Shona Customs: Essays by African Writers, ed. Clive and Peggy Kileff (Gweru: Mambo Press, 1970), 47. 
um. Bourdillon provides detailed explanations of the ritual process that led to the recognition of one as a svikiro. ${ }^{31}$ Once a svikiro, one would then receive divine communications from Mwari through ancestral spirits. It should be noted that the will of Mwari and that of the ancestors are always the same. Ecstatic behaviour often characterised the medium's possession by the spirit. This could be induced through music and/or through sniffing tobacco. It is in the ecstatic state that the medium receives divine oracles. The medium could also receive oracles through dreams or visions. ${ }^{32}$

The svikiro is purely a medium who does not speak his/her mind, but the mind of the divine being. The process of being possessed is kusvikirwa, which means that the spirit arrives upon the medium. Using the Ndebele term isigojwana, Nthoi provides an adequate explanation of the role of the medium when he talks of the passivity of the medium versus the activity of the spirit. ${ }^{33}$ Thus during possession, the medium is not aware of what happens and is only informed by others after the possession. The svikiro even speaks in a completely different voice from his/her usual voice. ${ }^{34}$ If possessed by spirits of very ancient people, the medium was supposed to speak in the ancient dialect that was used by the spirits when they were still living.

The svikiro was responsible for appointment of kings. ${ }^{35}$ This was usually the role of tribal masvikoro (called mhondoro) who were responsible for naming the new king. Masvikiro were also consulted in matters of illness, which in most cases, were considered to be a result of the ancestors seeking the attention of the living for one reason or another. Masvikiro also inculcated morality among members of the family or tribe. During possession, the svikiro would reprimand those members of the family engaging in unacceptable acts. Thus a svikiro was the medium of the ancestors. A svikiro was not necessarily a divine healer, although some svikiro could have gifts of healing. I elaborate on the svikiro below as when I compare the Israelite prophet and the Shona svikiro.

\section{SVIKIRO AS THE EQUIVALENT OF THE HEBREW BIBLE PROPHET}

The above discussions of the prophet and the svikiro among the Israelites and the Shona respectively suggest that svikiro would have been the proper translation of prophet in Shona. There are indeed several similarities between a

31 Michael F. C. Bourdillon, The Shona Peoples (Gweru: Mambo Press, 1976) and Bourdillon, Where are the Ancestors?

32 Nthoi, Contesting Sacred Space, 28.

33 Nthoi, Contesting Sacred Space, 29.

34 Bourdillon, Shona Peoples, 236, says this was one mark of a true svikiro.

35 Dominic M. Mandaza, "Traditional Ceremonies which Persist," in Shona Customs: Essays by African Writers, ed. Clive Kileff and Peggy Kileff (Gweru: Mambo Press, 1970), 59. 
prophet in Israel and a svikiro among the Shona. Thus, that the decision to transliterate prophet in the Shona Bible can only be understood from the missionary's negative attitude towards the Shona religion. D. Mbuvayesango makes a very important observation when she says that in translating the Christian God into the Shona Mwari, the missionaries colonised and suppressed local divine powers. ${ }^{36}$ This is particularly so when one considers that although they considered Mwari to be the right translation of God, they rejected all other Shona ideas about Mwari. One such idea is that Mwari is manifested through vadzimu who mediates between Mwari and the people. Vadzimu, in turn, operates through spirit mediums (masvikiro), whom, using the examples of national spirit mediums such as Chaminuka, Kaguvi and Nehanda, Mbuvayesango describes as spokespersons of Mwari. Thus for Isabel Mukonyora,

The prophet's role is similar to that of individuals that are believed to be agents of mudzimu.... One can be a mudzimu waMwari (messenger of God), one who mediates between God and the community. ${ }^{37}$

For Bethwell A. Ogot svikiro is the right translation of prophet because,

Svikiro literally, means the person, vehicle or instrument through which gods and spirits communicate with the people. Thus a priest, rabbi or prophet in western culture....could be a svikiro in Shona society. ${ }^{38}$

He goes further to note that the svikiro should not be confused with a traditional medical practitioner ( $n$ 'anga) or with a fortune-teller. Rather, the svikiro was a priest, an intellectual, an educator and a leader all combined in one person. Ogot does not, however, underline the fact that what is most distinguished about a svikiro, just like the biblical prophet, is the divine call. Unlike a priest whose office is institutional, the svikiro's office, like that of a prophet, is charismatic. As indicated above, a svikiro operates under divine possession, sometimes in an ecstatic state.

Thomas Overholt, although not using the word svikiro, also sees spirit mediumship among the Shona as some form of prophecy. He says,

Among the Bantu-speaking peoples of what are today Zimbabwe and Zambia, prophecy occurs in a well-defined system of spirit

36 Mbuvayesango, "How Local," 63-77.

37 Isabel Mukonyora, Wandering a Gendered Wilderness: Suffering and Healing in an African Initiated Church (New York: Peter Lang, 2007), 87.

38 Bethwell A. Ogot, ed., Africa from the Sixteenth to the Eighteenth Century (California: University of California, 1992), 984. 
mediumship and in connection with the centralized cult of the highgod, Mwari. ${ }^{39}$

Similarly, Bourdillon, compares OT prophets with Shona medium spirits. He says, "The Shona certainly see parallels between their spirit mediums and the prophets described in the Bible." ${ }^{40}$ He also notes that the activities of Shona mediums appear similar to some of the activities of ancient Hebrew prophets, who emphasised the national identity both in their insistence on the religion of their ancestors with all its rules and taboos, and in their interest in the military activities of the nation. ${ }^{41}$ Other similarities include ecstatic behavior, preaching or teaching morality, responsibility for appointing/naming new kings and healing the ill.

Although there are many similarities, we need to acknowledge that there were a number of differences as well. Bourdillon notes, for example, that Shona mediums were to some extent constrained by public opinion. ${ }^{42}$ They usually spoke what was considered to be the general public opinion. Bourdillon gives an example of a medium who attempted to forbid the building of stores and schools in his domain on the grounds that these were European innovations out of keeping with the traditions of the ancestors. The medium was quickly discredited. The major difference, however, could have been the masvikiro's possession by the ancestral spirits, not by God. For this reason, the missionaries thought the Shona people worshipped ancestors as gods. With this understanding, they probably thought that the translation of prophet to svikiro would lead people back to "worshipping" ancestors. This was, however, a misunderstanding on the part of the missionaries. As has been argued by scholars of African Traditional Religion (ATR), Africans do not worship, but venerate (esteem/honour/respect) ancestors. ${ }^{43}$ Ancestors are therefore not gods, but the living dead who can communicate better with Mwari who is spirit.

One can therefore argue that the decision to transliterate prophet was a result of missionaries' denunciation of ATR. In the case of the Shona Bible, svikiro was supposed to be the correct translation of prophet. A number of African scholars have identified similarities between the religion of Israel and ATR. Temba L. J. Mafico sees the Israelite view of the gods of the fathers as

39 Thomas W. Overholt, "Spirit Medium among the Shona," in Prophecy in CrossCultural Perspective (Atlanta: Scholars Press, 1986), 230.

40 Michael F. C. Bourdillon, "Oracles and Politics in Ancient Israel," Man 12/1 (1977): 126.

41 Bourdillon, “Oracles,” 133. Spirit mediums played key roles in Zimbabwe's fight for independence from the time of the coming of the white colonial settlers to the time of the 1970s war of liberation.

42 Bourdillon, “Oracles,” 133.

43 For example Nthoi, Contesting Sacred Space, 27-32. 
similar to African ancestors. ${ }^{44}$ He does not discuss masvikiro (the spirit mediums) through which the living communicated with the living dead (ancestors), but he assumes that in his argument. For Amanze, writing about the Batswana of Botswana, Modimo (God) is transcendental, high and elevated so that human beings cannot approach him directly. ${ }^{45}$ The only way to access Him is through ancestral spirits who act as intermediaries. Thus the role of masvikiro in African Traditional Religion is the same as that of the prophets of the Israelite God and svikiro should be used to translate prophet.

\section{E CONCLUSION}

I appreciate the challenges of translating words from one language to the other. It is more challenging when translating religious ideas as each religion has its own cosmology which may not be found in another religion. This could be one reason why the missionaries avoided translating prophet into the vernacular languages of Africa. They possibly could not find the equivalence of a biblical prophet in the traditional religion. However, they decided to use the name Mwari for God, while svikiro was clearly the best translation for prophet. The missionaries' decision not to use this term can therefore only be explained in terms of their negative attitude towards the traditional religion. The decision to use Mwari but to avoid svikiro shows the power dynamics of the entire translation process. Including gender in the process, Ntloidibe-Kuswani presents the relationship thus;

The relationship between source (language) and receptor (language) is not equal. In fact, it smacks of both gender and colonial relationships, in which the man and colonizer are regarded as sources of knowledge, power and leadership, while the woman and colonized are the subjugated, the silenced, the ruled, and those guided to receive the coloniser's knowledge. ${ }^{46}$

This is the point that my paper presented. I suggest that new Shona Bible translations should use svikiro for prophet. Considering the central place of prophets in divine-human relations, prophet should be rendered in indigenous languages, not in transliterated form. African Christian theologians have over the years, taught us that Christianity can only be meaningful to its adherents when expressed using the socio-religious heritage and experience of the Africans. ${ }^{47}$ This is, in any event, the way in which Christianity developed into a world religion. Although its embryonic phase was within Judaism, it allowed

44 Temba L. J. Mafico, "The Biblical God of the Fathers and the African Ancestors," in The Bible in Africa: Transactions, Trajectories and Trends, ed. Gerald O. West and Musa W. Dube (Leiden: Brill, 2000), 480-489.

45 James N. Amanze, African Christianity in Botswana (Gweru: Mambo Press, 1998), 4-5.

46 Ntloidibe-Kuswani, “Translating,” 80.

47 Ezigbo, "Religion,” 189. 
itself to be adapted to different cultures as it spread from Jerusalem: from Jewish to Greek, Roman and other Western cultures. I have explored the translation of prophet in this paper, but conclude that the missionaries' negative attitude also explains the transliteration of priest into mupirisita, a subject that requires a separate study.

\section{BIBLIOGRAPHY}

Amanze, James N. African Christianity in Botswana. Gweru: Mambo Press, 1998. Anderson, Bernhard W. The Living World of the Old Testament. 4th edition. Harlow: Longman, 1993.

Baker, Mona. Translation and Conflict: A Narrative Account. London: Routledge, 2006.

Bourdillon, Michael F. C. The Shona Peoples. Gweru: Mambo Press, 1976. . "Oracles and Politics in Ancient Israel.” Man 12/1 (1977): 124-140. . Where are the Ancestors? Changing Culture in Zimbabwe. Harare: UZ Publications, 1997.

Dube, Musa W. "Consuming a Cultural Time Bomb: Translating Badimo into 'Demons' in the Setswana Bible.” JSNT 73 (1999): 33-59.

Ezigbo, Victor I. "Religion and Divine Presence: Appropriating Christianity from within African Indigenous Religions’ Perspective.” Pages 187-204 in African Traditions in the Study of Religion in Africa. Edited by Afe Adogame, Ezra Chitando, and Bolaji Bateye. Surrey: Ashgate, 2013.

Fohrer, Georg. Introduction to the Old Testament. London: SPCK, 1976.

Gundani, Paul H. "Views and Attitudes of Missionaries toward African Religion in Southern Africa during the Portuguese Era.” R\&T 11 (2004): 298-312.

Hodgson, Janet. "A Battle for Sacred Power: Christian Beginnings among the Xhosa." Pages 68-88 in Christianity in South Africa: A Political, Social and Cultural History. Edited by Richard Elphick and Rodney Davenport. Claremont: David Philip, 1997.

Lindblom, Johannes. Prophecy in Ancient Israel. Oxford: B. Blackwell, 1962.

Mafico, Temba L. J. "The Biblical God of the Fathers and the African Ancestors.” Pages 480-489 in The Bible in Africa: Transactions, Trajectories and Trends. Edited by Gerald O. West and Musa W. Dube. Leiden: Brill, 2000.

Mandaza, Dominic M. “Traditional Ceremonies which Persist.” Pages 54-60 in Shona Customs: Essays by African Writers. Edited by Clive Kileff and Peggy Kileff. Gweru: Mambo Press, 1970.

Mbuvayesango, Dora R. "How Local Divine Powers were suppressed: A Case of Mwari of the Shona.” Pages 63-77 in Other Ways of Reading: African Women and the Bible. Edited by Musa W. Dube. Atlanta: Society of Biblical Literature, 2001.

Jacobus W. Melanchton., ed. A New Standard Bible Dictionary. New York: Funk \& Wagnalls Company, 1925.

Mojola, Aloo O. "Post-colonial Translation Theory and the Swahili Bible.” Pages 77104 in Bible Translation and African Languages. Edited by Gosnell L. O. R. Yorke and Peter M. Renju. Nairobi: Acton Publishers, 2004.

Mukonyora, Isabel. Wandering a Gendered Wilderness: Suffering and Healing in an African Initiated Church. New York: Peter Lang, 2007. 
834 Togarasei, “The Prophet and Divine,” OTE 30/3 (2017): 821-834

Nthoi, Leslie S. Contesting Sacred Space: A Pilgrimage Study of the Mwali Cult of Southern Africa. Trenton: Africa World Press, 2006.

Ntloidibe-Kuswani, Gomang S. "Translating the Divine: The Case of Modimo in the Setswana Bible.” Pages 77-97 in Other Ways of Reading: African Women and the Bible. Edited by Musa W. Dube. Atlanta: Society of Biblical Literature, 2001.

Ogot, Bethwell A., ed. Africa from the Sixteenth to the Eighteenth Century. California: University of California, 1992.

Overholt, Thomas W. "Spirit Medium among the Shona.” Pages 230-248 in Prophecy in Cross-Cultural Perspective. Atlanta: Scholars Press, 1986.

Ringgren, Helmer. "Prophecy in the Ancient Near East.” Pages 1-11 in Israel's Prophetic Tradition: Essays in Honour of Peter Ackroyd. Edited by Richard Coggins, Anthony Phillips, and Michael Knibb. Cambridge: Cambridge University Press, 1982.

Setiloane, Gabriel M. The Image of God among the Sotho-Tswana. Rotterdam: A. A. Balkema, 1976.

Stanley, Dean A. P. History of the Jewish Church. New York: Charles Scribner's Sons, 1891.

Togarasei, Lovemore. “The Shona Bible and Politics of Bible Translation,” SWC 15/1 (2007): 51-64.

. "Paul and Interreligious Dialogue: Insights for Mission in Africa.” Miss 43/2 (2015): 153-165.

Zvarevashe, Ignatius M. "Shona Religion.” Pages 44-47 in Shona Customs: Essays by African Writers. Edited by Clive Kileff and Peggy Kileff. Gweru: Mambo Press, 1970.

Wolf, Hans W. Hosea. Philadelphia: Fortress Press, 1988.

Prof. Lovemore Togarasei, University of Botswana, Gaberone. Visiting Research Professor at the RITR at the University of South Africa. Email: ltogarasei@yahoo.com 